\title{
Workplace noise exposure and serum testosterone in men enrolled in the 1999-2004 National Health and Nutrition Examination Survey
}

\author{
Angel M. Dzhambov \\ Department of Hygiene and Eco medicine, Faculty of Public Health, Medical University of Plovdiv, Bulgaria
}

[Received in January 2016; CrossChecked in January 2016; Accepted in July 2016]

\begin{abstract}
There is compelling evidence from animal experiments that noise exposure suppresses testosterone in males by affecting the hypothalamic-pituitary-testicular axis. Virtually nothing is known about its effect in humans. Therefore, the aim of this study was to explore the association between occupational noise exposure and serum testosterone in a representative sample of the general population. The sample has been taken from the National Health and Nutrition Examination Survey (NHANES) data for the period between 1999 and 2004 and is limited to employed men aged 16-85+ years at the time. The associations between noise exposure (either established according to the Occupational Information Network - O*NET categories or self-reported) and total and free testosterone (TT and FT, respectively) were analysed using linear regression models with increasing adjustments. In the fully adjusted model $(\mathrm{n}=414)$, the third quartile of the $\mathrm{O} * \mathrm{NET}$ noise exposure was associated with lower TT and FT, which reached statistically significant decrease of $-58.32 \mathrm{ng} \mathrm{dL}^{-1}(95 \% \mathrm{CI}$ : -111.22 , $-5.42)$ and $-1.58 \mathrm{ng} \mathrm{dL}^{-1}(95 \% \mathrm{CI}:-2.98,-0.18)$, respectively. In stratified analyses, younger, lower income, normal weight, better hearing, and workers not using hearing protection at work experienced significantly more severe adverse effects than the rest. The odds for hypogonadism (TT<300 ng dL-1) did not significantly rise with one interquartile range increment in O*NET noise exposure (OR=1.24, $95 \%$ CI: $0.64,2.39$ ). Self-reported loud noise exposure did not significantly decrease TT when all men were considered $(\mathrm{n}=214)$ and only in the men $\geq 37$ years did it decrease TT significantly by $-87.55 \mathrm{ng} \mathrm{dL}^{-1}$ ( $95 \%$ CI: - $158.35,-16.74)$. In conclusion, noise exposure was associated with lower TT and FT only in some population subgroups and these associations were non-linear.
\end{abstract}

KEY WORDS: hypogonadism; noise exposure; occupational noise; $O * N E T$; testosterone

Noise pollution is a widely recognised risk factor for hearing impairment, cardiovascular diseases, psychosocial dysfunction, cognitive impairment, and adverse pregnancy outcomes (1). Researchers have recently been looking into its relationship with some emerging health endpoints such as diabetes (2), obesity (3), rheumatoid arthritis (4), and even cancer (5). Virtually nothing is known, however, about its effect on male androgen status, which has escaped the spotlight of scientific interest.

Testosterone in men is a steroid hormone produced by the testes, stimulated by the pituitary luteinizing hormone $(\mathrm{LH})$, which is in turn released under the pulsatile control of the gonadotropin-releasing hormone $(\mathrm{GnRH})$ synthesised by the hypothalamus (6). Testosterone is vital for male sexual maturation and development, cognitive performance, psychosocial functioning, body composition, and metabolic control (7). However, the hypothalamic-pituitary-testicular (HPT) axis is sensitive to stress, which could disrupt its normal function and lead to functional hypogonadotropic hypogonadism (8). Under stress, be it psychosocial or

Correspondence to: Angel M. Dzhambov, MD, Department of Hygiene and Eco Medicine, Faculty of Public Health, Medical University of Plovdiv, 15A Vassil Aprilov Boulevard, 4002 Plovdiv, Bulgaria;

e-mail: angelleloti@gmail.com physical in nature, the normal response of the neuroendocrine system is to shift the balance to the hypothalamicpituitary-adrenal (HPA) axis. The release of corticotropinreleasing $(\mathrm{CRH})$ hormone and subsequent raise in adrenocorticotropic hormone and cortisol inhibit the neuronal secretion of GnRH and suppress its pulsatile release. HPT axis is further suppressed at its lower levels, which may ultimately reduce serum testosterone levels (9).

Because environmental noise acts as a stressor and stimulates the HPA axis, it has been implicated as a risk factor for testosterone deficiency (10-12). There is compelling evidence from animal experiments that chronic noise exposure is associated with reduced testosterone in males: a meta-analysis (12) pooled seven laboratory studies and found that rodents exposed to about $100 \mathrm{~dB}$ for several weeks had more than two standard deviations lower serum testosterone than the controls. The longer the exposure was, the larger the adverse effect. In humans, Wegiel et al. (13) found no significant differences in fasting and after-work testosterone concentrations in workers exposed to noise and whole-body vibration, while an inverse univariate association between traffic noise and testosterone was observed among men enrolled in the Caerphilly Study (14). Evidence from occupational research about the effects of 
general occupational stress on testosterone levels, semen quality, and fertility is also controversial (9). Mental stress at work was associated with lower total testosterone (TT) levels, depending on the specific job type (15), but other studies failed to establish an association between job stress and male hormones $(16,17)$.

Epidemiological research however has not explicitly focused on the effects of noise exposure on male androgen status. Such evidence is of particular importance, given the burden of disease associated with hypogonadism and related complications $(18,19)$. Therefore, the aim of this study was to explore the association between occupational noise exposure and serum testosterone in a representative sample of the general population.

\section{PARTICIPANTS AND METHODS}

\section{Study population}

The study sample is based on the National Health and Nutrition Examination Survey (NHANES), an ongoing series of cross-sectional surveys repeated every two years in the United States (US) and conducted by the National Center for Health Statistics (NCHS). The NHANES employs multistage random sampling to ensure a nationallyrepresentative sample of the non-institutionalised civilian population resident in the US at the time of enrolment. Self-reported data from a household interview are combined with data from subsequent medical examinations and laboratory tests carried out at a mobile examination centre $(20,21)$.

Our study used combined data from three consecutive waves of the NHANES (1999-2004) (20). Those were selected because they contained information on measured serum testosterone in male participants as well as their current occupation classification. The three waves were merged into one 1999-2004 NHANES dataset in order to increase the sample size. The response rate for men across different age groups and NHANES waves was $>70 \%$ (22). The 1999-2004 NHANES dataset was restricted to employed men with known occupation classification $(n=5,214)$. Of those, 4,459 had missing data on TT; noise exposure (according to the Occupational Information Network, aka O*NET) could not be assigned to 24 participants, and 3,001 had no data on self-reported exposure to loud noise. Some of the covariates also had missing data. Thus the final sample for the complete-case multivariate models for $\mathrm{O}$ NET noise exposure ranged from 745 (age-adjusted model) to 414 (fully-adjusted model). The model for self-reported exposure to loud noise included 214 cases.

\section{Ethics}

The 1999-2000, 2001-2002, and 2003-2004 waves of the NHANES were approved by the NCHS Institutional
Review Board (protocol number \#98-12). All information collected in the survey is kept strictly confidential and privacy is protected by public laws (21). Therefore no additional ethics approval was necessary for this secondary analysis.

\section{Blood samples and hormonal measurements}

In the NHANES series, morning blood samples were drawn after an overnight fast and collected using standard sampling tubes or tubes containing separating gel. Serum was separated from blood and kept in deep-freeze storage (23). TT (ng $\mathrm{mL}^{-1}$ ) and sex hormone-binding globulin (SHBG) (nmol L-1) concentrations were measured by electrochemiluminescence immunoassays using Elecsys 2010 system (Roche Diagnostics, Laval, QC, Canada) (23). TT values were converted to $\mathrm{ng} \mathrm{dL}^{-1}$ for this secondary study. Free testosterone (FT) and bioavailable testosterone fractions were also calculated for this secondary study according to Vermeulen's equations, using as input TT, SHBG, albumin and association constant values $\left(37^{\circ} \mathrm{C}\right)$ for the interactions of testosterone with SHBG and albumin (24). These calculations were done in an Excel spreadsheet (25). The threshold for hypogonadism was TT $<300 \mathrm{ng} \mathrm{dL}^{-1}$ (26). Albumin $\left(\mathrm{g} \mathrm{dL}^{-1}\right)$ was measured with the bromocresol purple binding agent and the Boehringer Manneheim Diagnostics (BMD, Indianapolis, IN) albumin system (23). The statistical analysis in this study was restricted to TT and FT, since the effects on bioavailable testosterone followed a similar pattern as those on FT.

\section{Exposure assessment}

The 1999-2004 NHANES sample is population-based, which means that it includes people from diverse occupational groups (including different white-collar workers) and precludes the use of conventional noise jobexposure matrices, limited to occupations and industries with high noise exposure $(27,28)$. Because of this, we employed a method to estimate noise exposure as previously described by Choi et al. $(27,28)$ in their studies of the relationship occupational noise-hearing loss within the NHANES. The Occupational Information Network $\left(\mathrm{O}^{*} \mathrm{NET}\right)$ is an on-line database with information about characteristics of various occupations defined by Standard Occupational Classification taxonomy. One of these characteristics is noise exposure assessed through responses to the question "In your current job, how often are you exposed to sounds and noise levels that are distracting and uncomfortable?", ranging from 1 through 5 (29). According to Choi et al. $(27,28)$, an averaged weighted noise score representing the probability of a worker in a certain job category being exposed to "distracting and uncomfortable sounds and noise" was assigned to the participants in our 1999-2004 NHANES dataset. The O*NET noise exposure could not be assigned to 24 participants. The $\mathrm{O} *$ NET noise exposure score was divided into quartiles and included as 
a categorical variable in the main models, and as continuous variable (per one interquartile range increase) in secondary analyses.

The question on self-reported noise in the current job included in the NHANES questionnaire referred to "loud noise" exposure, where "loud" was defined as so loud that participants had to speak in a raised voice to be heard. This noise indicator was used in secondary analyses as a proxy for the threshold of $66 \mathrm{~dB}$ (30). This variable, however, had a large amount of missing information $(n=3$ 001) in our 1999-2004 NHANES dataset.

\section{Other covariates}

Based on prior theory about individual and occupational factors associated with male androgens $(6,7)$, we included information about some important covariates. The demographic set included age (16-30, 31-40, 41-50, 51-60, 61-70, and $>70$ years), race/ethnicity (non-Hispanic white, non-Hispanic black, Mexican American, other), annual family income $(<\$ 25,000, \$ 25,000-\$ 55,000$, and $\geq \$ 55,000)$, and education (lower than high school, high school including GED, higher than high school).

Participants who had had at least 12 alcoholic beverages in the past year were classified as drinkers. Smoking status included never smokers ( $<100$ cigarettes in lifetime), former smokers $(\geq 100$ cigarettes in lifetime, but currently do not smoke), and current smokers ( $\geq 100$ cigarettes in lifetime and currently smoke). The total amount of protein, carbohydrates, fat, and dietary fibre was calculated (in grams) based on a detailed dietary diary for one preceding day (31).

Body mass index was calculated as weight $(\mathrm{kg})$ divided by height-squared $\left(\mathrm{m}^{2}\right)$. Physical activity over the past 30 days included the following categories: inactive $(<10$ minutes of moderate and $<10$ minutes of vigorous physical activity), moderate ( $\geq 10$ minutes of moderate and $<10$ minutes of vigorous physical activity), vigorous $(<10$ minutes of moderate and $\geq 10$ minutes of vigorous physical activity), and moderate + vigorous ( $\geq 10$ minutes of moderate and $\geq 10$ minutes of vigorous physical activity).

Whole blood lead ( $\left.\mu \mathrm{mol} \mathrm{L}{ }^{-1}\right)$ and cadmium (nmol L-1) measurements were based on light absorption method by ground-state atoms of cadmium and lead using PerkinElmer Model SIMAA 6000 simultaneous multi-element atomic absorption spectrometer with Zeeman background correction (23).

Self-reported general condition of hearing was defined as "good", "little trouble", "lot of trouble/deaf". Information on hearing protection use in the current job (yes, no) and length of service (number of months working in the current main job) was extracted as well.

\section{Data analysis}

The 1999-2004 NHANES dataset was first screened for missing data. Each analysis was run on complete-case data, and cases with missing data were excluded; hence the variations in sample sizes. As an outcome variable, TT was checked for distributional normality, which was achieved after deleting nine outliers, but without any transformations. The univariate associations between testosterone and other variables were explored using Pearson's chi-square test, ANOVA, and the $t$-test.

The association between the O*NET-assigned noise exposure and TT/FT was explored using linear regression models with increasing adjustments: Model 1 (ageadjusted), Model 2 (additionally adjusted for race/ethnicity, annual family income, education, physical activity status, and body mass index), Model 3 (additionally adjusted for protein intake, carbohydrate intake, total fat intake, fibre intake, alcohol drinking status, smoking status, blood lead and blood cadmium), and Model 4 (additionally adjusted for the length of service, general hearing, and use of hearing protection at work). To test for potential effect modifiers, Model 4 was stratified by participants' median age $(<37$ year vs $\geq 37$ years), race/ethnicity, annual family income, body mass index, general hearing status, and hearing protection use. Overall interactions between $\mathrm{O} * \mathrm{NET}$ quartiles and the potential effect modifiers were tested at the relaxed $\mathrm{p}<0.20$ level using the Wald test.

Weighted logistic regression, adjusted for the same covariates as Model 4, was employed to test the effect of $\mathrm{O}^{*}$ NET noise exposure (per one interquartile range increase) on hypogonadism ( $\mathrm{TT}<300 \mathrm{ng} \mathrm{dL}^{-1}$ ).

The complex sampling design of the NHANES and the different selection probabilities were incorporated in the analyses using stratification, clustering, and weighing. Three types of weights are available and should be applied to the NHANES dataset, depending on the variables used in the analysis, because the selection of the questionnaire, laboratory, and dietary subsamples differs and does not include exactly the same individuals. Statistical tests involving questionnaire data alone were weighted by the "6-year interview" weight, those involving laboratory variables by the "6-year interview and MEC" weight, and those involving dietary variables by the " 6 -year dietary one day" weight (32). Results were considered statistically significant at $\mathrm{p}<0.05$. Data were processed with SPSS v. 17 (SPSS Inc. Released 2008. SPSS Statistics for Windows, Version 17.0. Chicago, IL, USA).

\section{RESULTS}

All participants in our 1999-2004 NHANES dataset were men with weighted mean age of 39.59 years $(\mathrm{SE}=0.28$ years), ranging from 16 to $85+$ years. Elderly people over 60 were underrepresented because the analyses were limited to those currently at work. Most were non-Hispanic whites, with high school education and annual family income of $\$ 25,000-\$ 50,000$. Detailed sample characteristics are reported in Table 1. 
Table 1 Demographic data, dietary information, lifestyle factors, and mean testosterone concentrations

\begin{tabular}{|c|c|c|c|c|c|c|}
\hline & $\begin{array}{l}\text { All men } \\
\text { N ( \%) }\end{array}$ & p-value & $\begin{array}{c}\text { Total } \\
\text { testosterone } \\
\left(\text { ng dL d } \text { d }^{-1}\right) \\
\text { Mean (SE) }\end{array}$ & p-value & 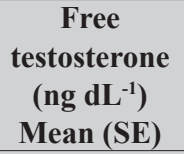 & p-value \\
\hline Age & & $<0.001$ & & 0.011 & & $<0.001$ \\
\hline $16-30$ & $1937(28.41)$ & & $587.24(17.29)$ & Reference & $13.62(0.49)$ & Reference \\
\hline $31-40$ & $1015(25.02)$ & & $542.16(19.36)$ & 0.385 & $11.62(0.31)$ & 0.002 \\
\hline $41-50$ & $1011(24.47)$ & & $485.98(21.86)$ & 0.003 & $10.17(0.51)$ & $<0.001$ \\
\hline $51-60$ & $693(15.66)$ & & $433.63(18.83)$ & $<0.001$ & $7.89(0.32)$ & $<0.001$ \\
\hline $61-70$ & $402(4.85)$ & & $449.78(34.58)$ & 0.007 & $7.50(0.31)$ & $<0.001$ \\
\hline$>70$ & $147(1.59)$ & & $401.02(56.16)$ & 0.011 & $6.13(0.84)$ & $<0.001$ \\
\hline Race/ethnicity & & $<0.001$ & & $<0.001$ & & 0.002 \\
\hline Non-Hispanic white & $2381(71.60)$ & & $503.52(11.67)$ & Reference & $10.55(0.25)$ & Reference \\
\hline Non-Hispanic black & $1010(9.19)$ & & $611.10(22.50)$ & $<0.001$ & $13.00(0.62)$ & 0.002 \\
\hline Mexican American & $1422(9.24)$ & & $532.71(16.93)$ & 0.344 & $11.56(0.32)$ & 0.027 \\
\hline other & $392(9.97)$ & & $531.51(28.50)$ & 1.000 & $12.02(0.82)$ & 0.275 \\
\hline Income & & $<0.001$ & & 0.010 & & 0.047 \\
\hline$<\$ 25,000$ & $1597(23.69)$ & & $565.32(18.13)$ & Reference & $12.05(0.53)$ & Reference \\
\hline$\$ 25,000-\$ 50,000$ & $1598(32.39)$ & & $506.38(13.31)$ & 0.025 & $10.74(0.28)$ & 0.052 \\
\hline$>\$ 55,000$ & $1655(43.92)$ & & $510.15(17.25)$ & 0.010 & $10.80(0.32)$ & 0.047 \\
\hline Education & & $<0.001$ & & 0.001 & & 0.003 \\
\hline less than high school & $1743(19.15)$ & & $583.24(22.87)$ & Reference & $12.33(0.57)$ & Reference \\
\hline $\begin{array}{l}\text { high school diploma } \\
\text { (incl. GED) }\end{array}$ & $1275(26.29)$ & & $537.50(16.51)$ & 0.232 & $11.37(0.41)$ & 0.321 \\
\hline more than high school & $2182(54.56)$ & & $489.57(12.85)$ & 0.001 & $10.41(0.27)$ & 0.003 \\
\hline Body mass index & & $<0.001$ & & $<0.001$ & & $<0.001$ \\
\hline underweight & $84(1.23)$ & & $778.87(47.27)$ & 0.027 & $14.02(0.67)$ & 0.038 \\
\hline normal weight & $1631(30.86)$ & & $638.27(17.22)$ & Reference & $12.47(0.41)$ & Reference \\
\hline preobese & $1873(40.59)$ & & $489.76(13.99)$ & $<0.001$ & $10.65(0.31)$ & 0.002 \\
\hline obese & $1236(27.31)$ & & $413.62(16.15)$ & $<0.001$ & $9.75(0.35)$ & $<0.001$ \\
\hline Protein (g) & & $<0.001$ & & 0.430 & & 0.145 \\
\hline$<65.87$ & $1160(21.13)$ & & $508.95(18.10)$ & Reference & $10.92(0.47)$ & Reference \\
\hline $65.87-122.31$ & $2323(51.58)$ & & $514.16(16.78)$ & 1.000 & $10.67(0.37)$ & 1.000 \\
\hline$>122.31$ & $1160(27.28)$ & & $548.11(30.00)$ & 0.430 & $12.19(0.61)$ & 0.145 \\
\hline Carbohydrate (g) & & $<0.001$ & & 0.104 & & 0.033 \\
\hline$<219.74$ & $1161(23.42)$ & & $474.99(19.44)$ & Reference & $10.12(0.46)$ & Reference \\
\hline $219.74-409.03$ & $2321(51.62)$ & & $531.76(14.46)$ & 0.116 & $11.16(0.40)$ & 0.303 \\
\hline$>409.03$ & $1161(24.96)$ & & $537.91(29.38)$ & 0.104 & $11.82(0.65)$ & 0.033 \\
\hline Fiber (g) & & & & 0.862 & & 1.000 \\
\hline$<9.90$ & $1160(22.75)$ & & $513.70(17.77)$ & Reference & $11.23(0.38)$ & Reference \\
\hline $9.90-22.82$ & $2322(52.20)$ & & $520.86(13.79)$ & 1.000 & $11.23(0.36)$ & 1.000 \\
\hline$>22.82$ & $1161(25.04)$ & & $535.16(23.35)$ & 0.862 & $11.04(0.56)$ & 1.000 \\
\hline Fat (g) & & $<0.001$ & & 0.492 & & 0.326 \\
\hline$<60.11$ & $1160(22.23)$ & & $510.66(20.07)$ & Reference & $10.76(0.57)$ & Reference \\
\hline $60.11-125.16$ & $2323(50.27)$ & & $511.97(13.51)$ & 1.000 & $10.85(0.33)$ & 1.000 \\
\hline$>125.16$ & $1160(27.50)$ & & $551.31(26.60)$ & 0.492 & $12.00(0.65)$ & 0.326 \\
\hline Alcohol drinking & & $<0.001$ & & 0.455 & & 0.270 \\
\hline no & $629(15.50)$ & & $497.41(24.24)$ & & $10.38(0.46)$ & \\
\hline yes & $3193(84.50)$ & & $516.33(10.19)$ & & $10.92(0.26)$ & \\
\hline Smoking status & & $<0.001$ & & $<0.001$ & & $<0.001$ \\
\hline never-smoker & $2012(46.79)$ & & $490.72(12.92)$ & Reference & $10.83(0.23)$ & Reference \\
\hline current-smoker & $1204(28.20)$ & & $598.71(15.06)$ & $<0.001$ & $12.34(0.44)$ & 0.007 \\
\hline former-smoker & $1119(25.01)$ & & $454.91(20.07)$ & 0.132 & $9.01(0.35)$ & $<0.001$ \\
\hline
\end{tabular}




\begin{tabular}{|c|c|c|c|c|c|c|}
\hline & $\begin{array}{l}\text { All men } \\
\text { N ( \%) }\end{array}$ & p-value & $\begin{array}{c}\text { Total } \\
\text { testosterone } \\
\left(\text { ng dL dL } \text { dL }^{-1}\right) \\
\text { Mean (SE) }\end{array}$ & p-value & $\begin{array}{c}\text { Free } \\
\text { testosterone } \\
\left(\text { ng dL } \mathbf{d L}^{-1}\right) \\
\text { Mean (SE) }\end{array}$ & p-value \\
\hline Physical activity & & $<0.001$ & & 0.314 & & 0.082 \\
\hline inactive & $1807(30.43)$ & & $503.63(17.78)$ & Reference & $10.49(0.38)$ & Reference \\
\hline moderate & $1091(23.96)$ & & $496.48(17.04)$ & 1.000 & $10.70(0.40)$ & 1.000 \\
\hline vigorous & $910(16.28)$ & & $534.58(21.30)$ & 0.876 & $11.33(0.31)$ & 0.303 \\
\hline moderate+vigorous & $1382(29.33)$ & & $540.82(16.82)$ & 0.314 & $11.55(0.40)$ & 0.082 \\
\hline Hearing & & $<0.001$ & & 0.006 & & 0.001 \\
\hline good & $4087(75.41)$ & & $538.35(10.26)$ & Reference & $11.53(0.26)$ & Reference \\
\hline little trouble & $983(21.97)$ & & $471.25(19.59)$ & 0.008 & $9.73(0.38)$ & $<0.001$ \\
\hline lot of trouble/deaf & $133(2.62)$ & & $435.15(35.86)$ & 0.006 & $8.80(0.85)$ & 0.005 \\
\hline Hearing protection & & $<0.001$ & & 0.784 & & 0.391 \\
\hline no & $2778(69.49)$ & & $515.92(11.35)$ & & $11.14(0.26)$ & \\
\hline yes & $1021(30.51)$ & & $522.29(21.61)$ & & $10.74(0.42)$ & \\
\hline $\begin{array}{l}\text { O*NET noise exposure } \\
\text { (quartiles) }\end{array}$ & & $<0.001$ & & 0.098 & & 0.271 \\
\hline$<2.84$ & $1209(28.56)$ & & $504.55(15.62)$ & Reference & $10.66(0.35)$ & Reference \\
\hline $2.84-3.37$ & $1680(31.27)$ & & $489.29(15.91)$ & 1.000 & $10.63(0.29)$ & 1.000 \\
\hline $3.37-4.16$ & $1208(19.29)$ & & $563.84(22.76)$ & 0.098 & $11.64(0.52)$ & 0.286 \\
\hline$>4.16$ & $1084(20.87)$ & & $544.02(13.34)$ & 0.183 & $11.45(0.38)$ & 0.271 \\
\hline Current exposure to loud noise & & 0.006 & & 0.237 & & 0.121 \\
\hline no & $997(46.26)$ & & $479.27(22.27)$ & & $10.22(0.45)$ & \\
\hline yes & $1211(53.74)$ & & $511.35(17.88)$ & & $10.99(0.39)$ & \\
\hline Cadmium (nmol L-1) & & $<0.001$ & & $<0.001$ & & 0.260 \\
\hline$<1.78$ & $1671(36.77)$ & & $487.47(13.02)$ & Reference & $11.04(0.26)$ & Reference \\
\hline $1.78-5.34$ & $2063(41.98)$ & & $495.87(16.21)$ & 1.000 & $10.49(0.35)$ & 0.311 \\
\hline$>5.34$ & $955(21.25)$ & & $610.89(20.34)$ & $<0.001$ & $11.91(0.48)$ & 0.260 \\
\hline Lead $\left.(\mu \mathrm{mol} \mathrm{L})^{-1}\right)$ & & $<0.001$ & & 0.009 & & 0.314 \\
\hline$<0.06$ & $1212(25.43)$ & & $489.20(19.19)$ & Reference & $11.49(0.40)$ & Reference \\
\hline $0.06-0.14$ & $2443(55.59)$ & & $508.63(14.63)$ & 1.000 & $10.75(0.36)$ & 0.314 \\
\hline$>0.14$ & $1034(18.98)$ & & $576.79(20.75)$ & 0.004 & $11.09(0.40)$ & 0.902 \\
\hline
\end{tabular}

Data source: CDC/NCHS-NHANES, 1999-2004.

Applied weights: "Interview" (descriptives without testosterone and macronutrients); "Interview and MEC Exam" (descriptives for testosterone); "Dietary day one" (descriptives for macronutrients).

p-values are associated with Pearson's chi-square test, ANOVA (with Bonferroni correction for multiple comparisons), or t-test

Unweighted median O*NET noise score was $3.56\left(25^{\text {th }}\right.$ and $75^{\text {th }}$ percentiles: $2.83,4.16$ ). Noise levels were lower among white participants, those with income $>\$ 50000$, and higher-than-high-school education level. Men with good hearing and those who did not use hearing protection at work had lower exposure (data not shown). NHANES occupational codes corresponding to $\mathrm{O}$ *NET noise exposure have been reported elsewhere $(27,28)$.

Weighted mean TT and FT concentrations were $519.10 \mathrm{ng} \mathrm{dL}^{-1}\left(\mathrm{SE}=9.65 \mathrm{ng} \mathrm{dL}^{-1}\right)$ and $11.01 \mathrm{ng} \mathrm{dL}^{-1}$ ( $\left.\mathrm{SE}=0.23 \mathrm{ng} \mathrm{dL}^{-1}\right)$, respectively; 78 men or $11.66 \%(95 \%$ CI: $9.07 \%, 14.87 \%$ ) were hypogonadal (TT<300 $\left.\mathrm{ng} \mathrm{dL}^{-1}\right)$. Figure 1 shows the frequency distribution of TT. It followed a normal curve, which allowed its inclusion in parametric tests. Testosterone levels declined with age (see Table 1). Whites had significantly lower testosterone than blacks. Testosterone was significantly higher in participants with lower income and education, lower body mass index, and in current smokers. Better hearing and higher blood level of cadmium and lead were also associated with higher testosterone. The relationship with $\mathrm{O}$ *NET noise exposure followed a non-linear trend, and testosterone was the lowest in the second quartile, but not significantly. The univariate relationship with self-reported loud noise exposure showed non-significantly higher testosterone among the exposed participants.

Table 2 shows the results of linear regression models for TT and FT with increasing adjustments. O*NET noise exposure 2.83-3.56 was associated with somewhat lower $\mathrm{TT}$, but the effect remained non-significant. In the quartile 3.56-4.16, however, TT was significantly lower than in the first quartile (in Models 3 and 4). According to their occupation group (NHANES codes: 18, 23, 27, 29, 32, 34, $37-40$ ), participants exposed to these O*NET noise levels were mostly blue-collar workers. The effects on FT followed a similar pattern. In Model 4, FT was significantly lower in the second and third quartiles in reference to the first. 


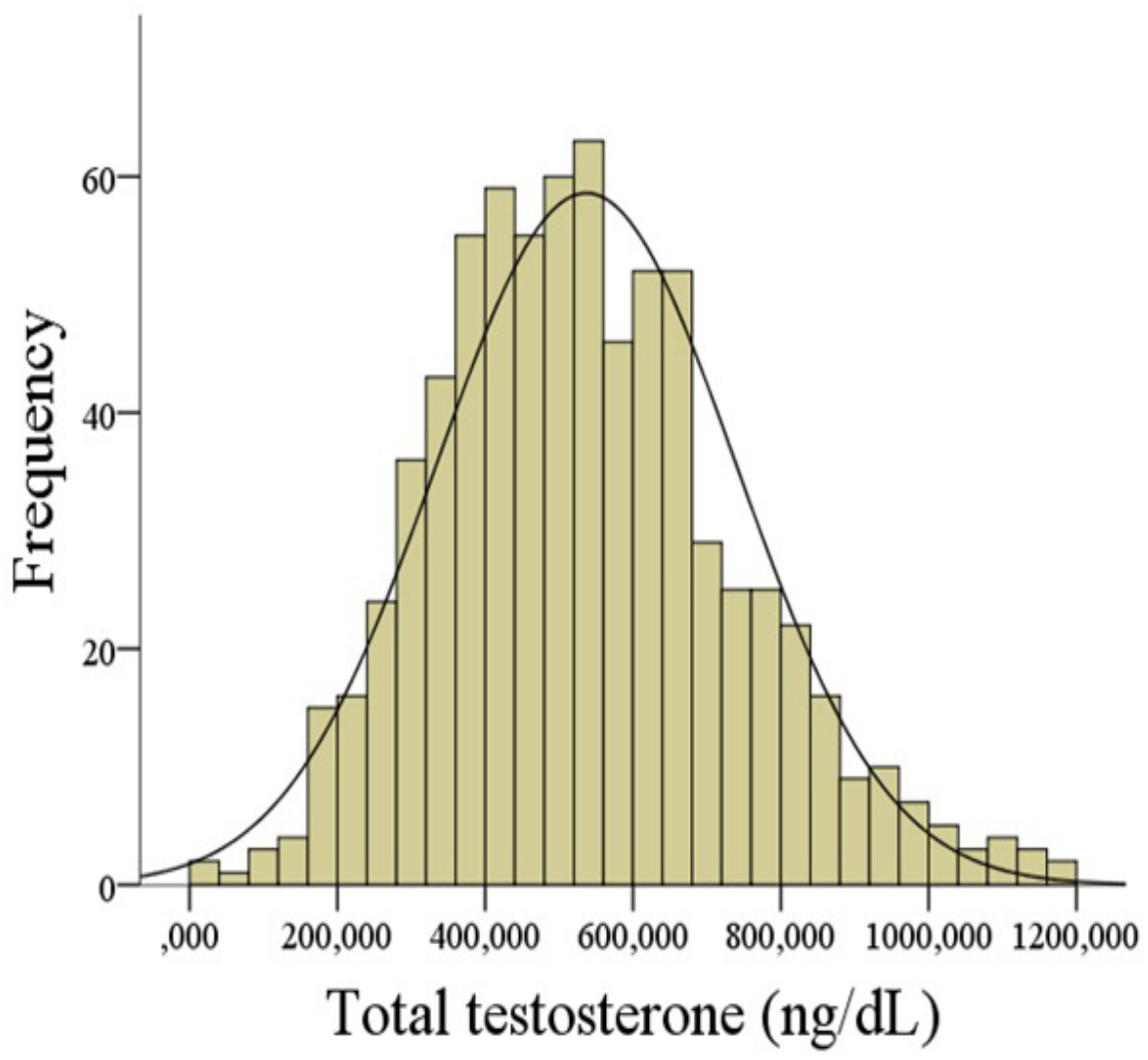

Figure 1 Frequency distribution of total testosterone concentrations Data source: CDC/NCHS-NHANES, 1999-2004

When Model 4 was run with hypogonadism as a dependent variable, the odds ratio for hypogonadism was 1.24 (95 \% CI: 0.64, 2.39) per one interquartile range increment in $\mathrm{O}$ *NET noise exposure. Of note, the statistical power for this logistic regression was low.

Figure 2 displays stratified analyses testing potential effect modifiers on the relationship between $\mathrm{O}$ NET interquartile range increase and TT. Younger participants, those with lower income, normal weight, better hearing, and those not using hearing protection at work showed more severe adverse effect on TT than the rest (at the relaxed $\mathrm{p}<0.20$ level).

Figure 3 displays the fully adjusted effect of current exposure to self-reported loud noise at work on TT concentrations among all men and then stratified by median age. The interaction with age was statistically significant: those exposed to loud noise and aged $\geq 37$ years experienced significant reduction in TT by $-87.55 \mathrm{ng} \mathrm{dL}^{-1}(95 \% \mathrm{CI}$ : $-158.35,-16.74)$ compared to unexposed participants.

\section{DISCUSSION}

Prior research offers scant insight into the role of noise as risk factor for testosterone deficiency. Our results have shown that for people in some occupation groups more frequent and higher noise exposure is associated with lower
TT and FT, but this relationship was non-linear and was significant only in some subgroups. The effect was statistically significant when the O*NET noise exposure level was moderate, suggesting that very high exposure levels may be counteracted by healthy worker effect or that those occupations may involve a confounding factor that we did not include in the models. Self-reported exposure to loud noise was also associated with lower TT, but the effect was statistically significant only among those aged $\geq 37$ years. Our findings are in line with the relationship established in animal experiments (12), but adequate comparisons cannot be made with epidemiological studies in humans.

We tested several potential effect modifiers of the relationship between $\mathrm{O}$ *NET noise exposure level and TT. Although previous studies have shown racial/ethnic differences in sex hormones (33-35), and that socioeconomic factors were more strongly associated with perceived stress in white men than in other racial/ethnic groups (36), we found no significant differences with respect to race/ ethnicity.

Regarding age, the noise effect on testosterone levels could be modified by changes in hormone levels occurring with the advancing age. According to some authors (37, 38), TT gradually decreases with age, whereas others admit greater variation after the age of 40 , but find no drop in 
mean TT $(39,40)$. In contrast, $\mathrm{LH}$ and SHBG concentrations rise with age (41-43). Older age is also associated with accumulation of stressful life events, which may, in turn, affect the stress hormone cortisol and its effects on TT (44). In our study, the adverse effect of noise was greater in young men (when we used O*NET exposure levels) or in those over 37 years of age (when we used self-reported exposure to loud noise). On one hand, advancing age may be associated with several and much stronger risk factors for low testosterone than noise exposure, which would explain why younger men were more affected by $\mathrm{O}^{*} \mathrm{NET}$ noise exposure. On the other hand, middle-aged men might be more sensitive to noise and perceive it as louder, in which case their attitude towards it could account for the stronger effect of self-reported loud noise exposure among those over 37 . These hypotheses could not be explored in this study.

That participants with better hearing and those not using hearing protection were at higher risk was anticipated, as was the fact that those with lower income were also more affected by workplace noise. As for the body mass index, adiposity is one of the leading risk factors for low testosterone, probably masking the effect of noise. Additional genetic and environmental influences on the HPT axis cannot be ruled out.

A comprehensive explanatory framework underlying the observed effects of noise has not yet been developed, nor has it been confirmed by other epidemiological studies; therefore, additional data are needed to give us a better understanding of this effect and whether it is true or due to chance, bias, or residual confounding.

\section{Strengths and limitations}

As far as we are aware, this study is the first to explore the epidemiological relationship between occupational noise and testosterone concentrations in men. Being based on the NHANES data, it is representative of the general US population. Another strength is controlling for important sociodemographic, behavioural, and workplace-related covariates. TT and FT concentrations were measured through validated laboratory methods, and two separate noise indicators were used.

However, there are some limitations. Owing to its crosssectional design, this study cannot make causal inferences between exposure and outcome. Nevertheless, if testosterone suppression in humans is a relatively short-term effect of noise as it is in animal experiments (12), then current occupational exposure is a biologically feasible risk factor, and the lack of long-term or lifetime exposure data may not be crucial.

The sample size was smallish due to the lack of testosterone measurements in most of the other NHANES waves and due to the exclusion of participants who were not currently working. In spite of this, statistically significant effects were detected. 


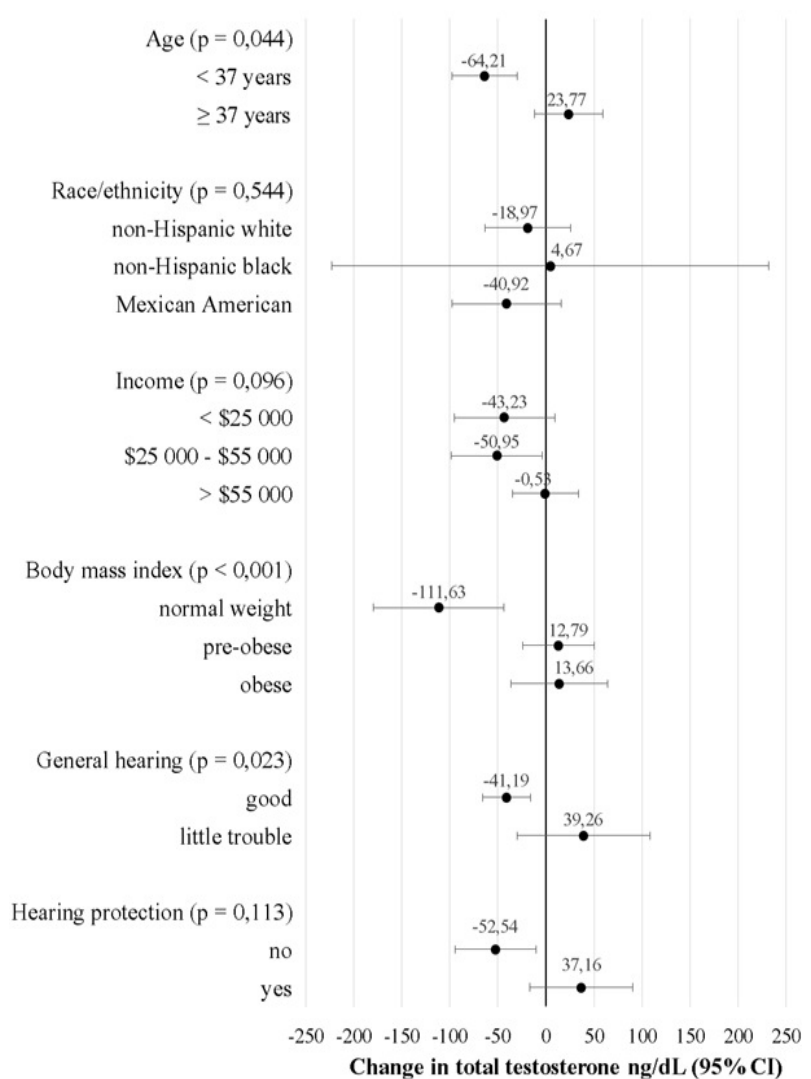

Figure 2 Association between one interquartile range increase (1.33) in $O^{*} N E T$ noise exposure and serum total testosterone (stratified analyses) $(n=414)$

Data source: CDC/NCHS-NHANES, 1999-2004.

p-values (Wald test) stand for statistical significance of interaction terms. Some categories of the moderators are omitted due to the low number of cases hindering stratification

The model is adjusted for age (categorical), racelethnicity, family income, education, physical activity status and body mass index (categorical), protein intake (continuous), carbohydrate intake (continuous), total fat intake (continuous), fiber intake (continuous), alcohol drinking status, smoking status, lead levels in blood (continuous) and cadmium levels in blood (continuous), length of service, general hearing, and hearing protection use at work. (When the model was stratified by the respective factor, it was dropped from the adjustment set). Applied weights: "Dietary day one"

Another issue is the exposure misclassification attributed to the exposure indicators used. The main analyses were based on the $\mathrm{O}$ *NET noise exposure classification for several reasons. First, it is independent of the participants and is therefore not prone to common method bias or self-report bias. Any misclassification rising from this indicator is likely to be non-differential and leads the effect towards the null. Secondly, assigning O*NET noise exposure allowed us to increase the sample size for the analyses and to capture the effect among white-collar workers for whom the job-exposure matrix was not available $(27,28)$. According to Choi et al. $(27,28)$, O*NET could serve as a surrogate for the job-exposure matrix for occupations not included in conventional matrices: "O*NET noise exposure data would allow us to perform epidemiologic studies of occupational noise exposure in the general population and to better understand the health effects of occupational noise exposure". Other researchers also found O*NET useful in the study of chronic diseases (45). However, O*NET does not take into account the actual job title/tasks performed by each worker nor is it a proxy for noise intensity in decibels at the individual participant level. Therefore, this study also explored the effect of self-reported exposure to loud noise, whose threshold, according to Lazarus, is around $66 \mathrm{~dB}(30)$. Nevertheless, researchers should extend this evidence by establishing an exposureresponse relationship between objective noise levels and testosterone concentrations.

Another limitation is that the effect of noise on LH could not be explored due to missing data. LH is hypothesised to be the key mediating link between noise stress and low testosterone, and should therefore be studied.

Finally, some covariates, previously linked to low testosterone (e.g., diabetes, opioid drug use, mercury exposure, and psychosocial stress), were not included in the analyses, because there many data were missing, threatening with the loss of power or over-adjustment. 


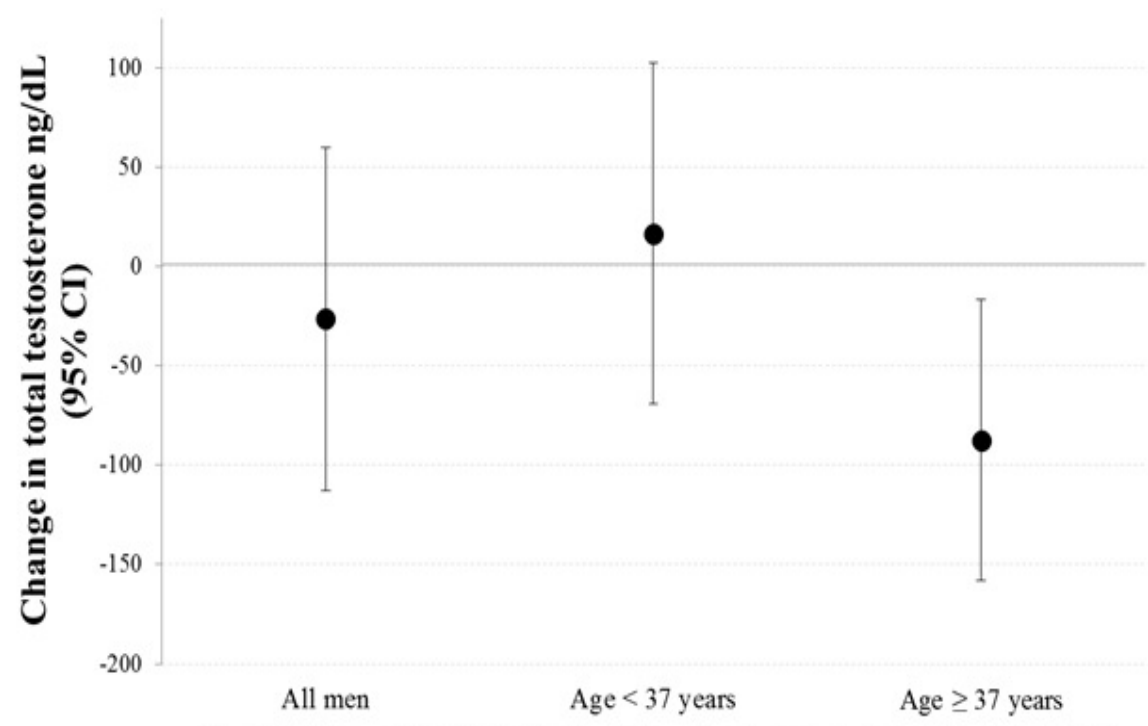

Currently exposed to loud noise at work (versus not exposed)

Figure 3 Association between self-reported loud noise exposure and serum total testosterone $(n=214)$

Data source: CDC/NCHS-NHANES, 1999-2004.

Reference category: not exposed.

The model is adjusted for age (categorical), racelethnicity, family income, education, physical activity status and body mass index (categorical), protein intake (continuous), carbohydrate intake (continuous), total fat intake (continuous), fiber intake (continuous), alcohol drinking status, smoking status, lead levels in blood (continuous) and cadmium levels in blood (continuous), length of service, general hearing, and hearing protection use at work. (When the model was stratified by age, it was dropped from the adjustment set). Applied weights: "Dietary day one"

\section{Future research}

Despite the limitations of this study, it addresses a new hypothesized health effect of noise exposure that has not been sufficiently explored in humans earlier. While testosterone deficiency is much more subtle as a public health problem than cardiovascular disease, its burden is nonetheless overwhelming. About four million Americans are affected by hypogonadism, and this number is expected to gradually increase in the decades to come due to the ageing of the population, increased life expectancy, and unhealthy lifestyle leading to greater obesity and sex-steroid dysregulation (46). Low testosterone is a risk factor for cardiovascular disease, obesity, and diabetes, bone mineral density loss, depression, impaired cognitive and social functioning, and overall mortality $(47,48)$. A follow-up study of 8,538 employed men in the US estimated that hypogonadal employees had greater health care costs and disability leave/medical absenteeism than the eugonadal employees (49). Cardiometabolic complications alone make low testosterone an important biomarker for morbidity and mortality in men (50), and meta-analyses have reported a significantly higher risk of cardiovascular disease-related and all-cause mortality among testosterone-deficient men $(18,19)$. Given that the pharmacological treatment of hypogonadism with testosterone replacement therapy, however safe, may still be associated with some adverse effects (51), environmental risk factors for low testosterone, such as noise, should be explored, and preventive measures established as needed.

\section{CONCLUSIONS}

Noise exposure was associated with significantly lower total and free testosterone only in some subgroups of active male workers aged 16-85+ years in the US general population. Younger participants, those with lower income, normal weight, better hearing, and not using hearing protection at work experienced more severe adverse effects than the rest. Self-reported exposure to loud occupational noise was associated with lower total testosterone only in workers aged $\geq 37$ years. This study explored a new hypothesized neuro-hormonal effect of noise exposure in humans.

\section{Acknowledgements}

The author is grateful to the National Center for Health Statistics of the United States for making the National Health and Nutrition Examination Survey data available. However, the author retains sole responsibility for the analyses, interpretations, and conclusions based on these data, which do not necessarily represent the views of the Centers for Disease Control and Prevention and the National Center for Health Statistics.

\section{Competing interests and funding}

The author has no relationships that could be construed as potential conflict of interest. This study was not funded. 


\section{REFERENCES}

1. Basner M, Babisch W, Davis A, Brink M, Clark C, Janssen S, Stansfeld S. Auditory and non-auditory effects of noise on health. Lancet 2014;383:1325-32. doi: 10.1016/S01406736(13)61613-X

2. Sørensen M, Andersen ZJ, Nordsborg RB, Becker T, Tjønneland A, Overvad K, Raaschou-Nielsen O. Long-term exposure to road traffic noise and incident diabetes: a cohort study. Environ Health Perspect 2013;121:217-22. doi: 10.1289/ehp. 1205503

3. Oftedal B, Krog NH, Pyko A, Eriksson C, Graff-Iversen S, Haugen M, Schwarze P, Pershagen G, Aasvang GM. Road traffic noise and markers of obesity - a population-based study. Environ Res 2015;138:144-53. doi: 10.1016/j. envres.2015.01.011

4. De Roos AJ, Koehoorn M, Tamburic L, Davies HW, Brauer M. Proximity to traffic, ambient air pollution, and community noise in relation to incident rheumatoid arthritis. Environ Health Perspect 2014;122:1075-80. doi: 10.1289/ ehp. 1307413

5. Roswall N, Eriksen KT, Hjortebjerg D, Jensen SS, Overvad K, Tjønneland A, Raaschou-Nielsen O, Sørensen M. Residential exposure to road and railway noise and risk of prostate cancer: A prospective cohort study. PLoS One 2015;10(8):e0135407. doi: 10.1371/journal.pone.0135407

6. Dandona P, Rosenberg MT. A practical guide to male hypogonadism in the primary care setting. Int J Clin Pract 2010;64:682-96. doi: 10.1111/j.1742-1241.2010.02355.x

7. Seftel A. Male hypogonadism. Part II: etiology, pathophysiology, and diagnosis. Int J Impot Res 2006; 18:2238. doi: 10.1038/sj.ijir.3901365

8. Guay AT, Jacobson J, Perez JB, Hodge MB, Velasquez E. Clomiphene increases free testosterone levels in men with both secondary hypogonadism and erectile dysfunction: who does and does not benefit? Int J Impot Res 2003;15:156-65. doi: 10.1038/sj.ijir.3900981

9. Jóźków P, Mędraś M. Psychological stress and the function of male gonads. Endokrynol Pol 2012;63:44-9. PMID: 22378097

10. Saki G, Jasemi M, Sarkaki AR, Fathollahi A. Effect of administration of vitamins $\mathrm{C}$ and $\mathrm{E}$ on fertilization capacity of rats exposed to noise stress. Noise Health 2013;15:194-8. doi: 10.4103/1463-1741.112374

11. Farzadinia P, Bigdeli M, Akbarzadeh S, Mohammadi M, Daneshi A, Bargahi A. Effect of noise pollution on testicular tissue and hormonal assessment in rat. Andrologia 2016. doi: 10.1111/and.12524 (Epub ahead of print)

12. Dzhambov A, Dimitrova D. Chronic noise exposure and testosterone deficiency -- meta-analysis and meta-regression of experimental studies in rodents. Endokrynol Pol 2015;66:39-46. doi: 10.5603/EP.2015.0007

13. Wegiel A, Pigoń-Wegiel A, Dec M. Wibracja ogólna niskich czestotliwości a stezenie testosteronu w surowicy krwi i wydalanie 17-ketosterydów z moczem u narazonych pracowników [Low frequency vibration and testosterone levels in blood serum and excretion of 17-ketosteroid in urine in exposed workers, in Polish]. Med Pr 1993;44:569-72. PMID: 8107572

14. Babisch W, Gallacher JE, Elwood PC, Ising H. Traffic noise and cardiovascular risk. The Caerphilly study, first phase.
Outdoor noise levels and risk factors. Arch Environ Health 1988;43:407-14. doi: 10.1080/00039896.1988.9935859

15. Theorell T, Karasek RA, Eneroth P. Job strain variations in relation to plasma testosterone fluctuations in working men: a longitudinal study. J Intern Med. 1990;227:31-6. doi: 10.1111/j.1365-2796.1990.tb00115.x

16. Hjollund NH, Bonde JP, Henriksen TB, Giwercman A, Olsen $\mathrm{J}$; Danish First Pregnancy Planner Study Team. Reproductive effects of male psychologic stress. Epidemiology 2004;15:217. doi: 10.1097/01.ede. $0000100289.82156 .8 \mathrm{~b}$

17. Hjollund NH, Bonde JP, Henriksen TB, Giwercman A, Olsen J; Danish First Pregnancy Planner Study Team. Job strain and male fertility. Epidemiology 2004;15:114-7. doi: 10.1097/01.ede. $0000100290.90888 .4 \mathrm{a}$

18. Corona G, Rastrelli G, Monami M, Guay A, Buvat J, Sforza A, Forti G, Mannucci E, Maggi M. Hypogonadism as a risk factor for cardiovascular mortality in men: a meta-analytic study. Eur J Endocrinol 2011;165:687-701. doi: 10.1530/ EJE-11-0447

19. Araujo AB, Dixon JM, Suarez EA, Murad MH, Guey LT, Wittert GA. Clinical review: Endogenous testosterone and mortality in men: a systematic review and meta-analysis. J Clin Endocrinol Metab 2011;96:3007-19. doi: 10.1210/ jc.2011-1137

20. Centers for Disease Control and Prevention (CDC), National Center for Health Statistics (NCHS). National Health and Nutrition Examination Survey Data. [displayed 23 January 2016]. Available at: http://www.cdc.gov/nchs/nhanes.htm

21. Centers for Disease Control and Prevention (CDC), National Center for Health Statistics (NCHS). About the National Health and Nutrition Examination Survey [displayed 23 January 2016]. Available at: http://www.cdc.gov/nchs/ nhanes/about nhanes.htm

22. National Center for Health Statistics, Centers for Disease Control and Prevention. NHANES Response Rates and Population Totals [displayed 23 January 2016]. Available at: http://www.cdc.gov/nchs/nhanes/response_rates_CPS.htm

23. Centers for Disease Control and Prevention (CDC), National Center for Health Statistics (NCHS). NHANES 2001-2002 Laboratory Data [displayed 23 January 2016]. Available at: http://wwwn.cdc.gov/Nchs/Nhanes/Search/DataPage. aspx?Component $=$ Laboratory\&CycleBeginYear $=2001$

24. Vermeulen A, Verdonck L, Kaufman JM. A critical evaluation of simple methods for the estimation of free testosterone in serum. J Clin Endocrinol Metab 1999;84:3666-72. doi: 10.1210/jcem.84.10.6079

25. Mazer NA. A novel spreadsheet method for calculating the free serum concentrations of testosterone, dihydrotestosterone, estradiol, estrone and cortisol: with illustrative examples from male and female populations. Steroids 2009;74:512-9. doi: 10.1016/j.steroids.2009.01.008

26. Paduch DA, Brannigan RE, Fuchs EF, Kim ED, Marmar JL, Sandlow JI. The laboratory diagnosis of testosterone deficiency. Urology 2014;83:980-8. doi: 10.1016/j. urology.2013.12.024

27. Choi YH, Hu H, Tak S, Mukherjee B, Park SK. Occupational noise exposure assessment using $\mathrm{O} * \mathrm{NET}$ and its application to a study of hearing loss in the US general population. Occup Environ Med 2012;69:176-83. doi: 10.1136/oem.2011.064758

28. Choi Y-H. Metals, noise, diet, and hearing loss. [ $\mathrm{PhD}$ thesis]. The University of Michigan, 2011 [displayed 23 January 
2016]. Available at: http://deepblue.lib.umich.edu/bitstream/ handle/2027.42/86370/yoonchoi_1.pdf?sequence $=1$

29. National Crosswalk Service Center, O*NET Occupations Reference Guide. Des Moines, IA, 2007 [displayed 23 January 2016]. Available at: http://www.workforceinfodb. org/ftp/download/onet12/ONET12UserGuide.pdf

30. Lazarus H. Prediction of verbal communication is noise - A review: Part 1. Appl Acoust 1986;19:439-64. doi 10.1016/0003-682X(86)90039-3

31. Centers for Disease Control and Prevention (CDC). National Center for Health Statistics (NCHS). National Health and Nutrition Examination Survey Dietary Data. Hyattsville, MD: U.S. Department of Health and Human Services, Centers for Disease Control and Prevention, [accessed January 232016 ]. Available from: http://wwwn.cdc.gov/Nchs/Nhanes/Search/ DataPage.aspx ?Component $=$ Dietary $\&$ CycleBeginYear $=$ 2001.

32. National Center for Health Statistics, Centers for Disease Control and Prevention. The National Health and Nutrition Examination Survey (NHANES). Analytic and Reporting Guidelines [displayed 23 January 2016]. Available at: http:// www.cdc.gov/nchs/data/nhanes/nhanes_03_04/nhanes analytic_guidelines_dec_2005.pdf

33. Rohrmann S, Nelson WG, Rifai N, Brown TR, Dobs A, Kanarek N, Yager JD, Platz EA. Serum estrogen, but not testosterone, levels differ between black and white men in a nationally representative sample of Americans. J Clin Endocrinol Metab 2007;92:2519-25. doi: 10.1210/jc.20070028

34. Rohrmann S, Sutcliffe CG, Bienstock JL, Monsegue D, Akereyeni F, Bradwin G, Rifai N, Pollak MN, Agurs-Collins $T$, Platz EA. Racial variation in sex steroid hormones and the insulin-like growth factor axis in umbilical cord blood of male neonates. Cancer Epidemiol Biomarkers Prev 2009;18:1484-91. doi: 10.1158/1055-9965.EPI-08-0817

35. Lopez DS, Peskoe SB, Joshu CE, Dobs A, Feinleib M, Kanarek N, Nelson WG, Selvin E, Rohrmann S, Platz EA. Racial/ethnic differences in serum sex steroid hormone concentrations in US adolescent males. Cancer Causes Control 2013;24:817-26. doi: 10.1007/s10552-013-0154-8

36. Rebbeck TR, Weber AL, Spangler E, Zeigler-Johnson CM. What stresses men? Predictors of perceived stress in a population-based multi-ethnic cross sectional cohort. BMC Public Health 2013;13:113. doi: 10.1186/1471-2458-13-113

37. Rohrmann S, Platz EA, Selvin E, Shiels MS, Joshu CE, Menke A, Feinleib M, Basaria S, Rifai N, Dobs AS, Kanarek $\mathrm{N}$, Nelson WG. The prevalence of low sex steroid hormone concentrations in men in the Third National Health and Nutrition Examination Survey (NHANES III). Clin Endocrinol (Oxford) 2011;75:232-9. doi: 10.1111/j.1365-2265.2011.04043.x

38. Simon D, Preziosi P, Barrett-Connor E, Roger M, Saint-Paul M, Nahoul K, Papoz L. The influence of aging on plasma sex hormones in men: the Telecom Study. Am J Epidemiol 1992;135:783-91. PMID: 1595678

39. Rhoden EL, Teloken C, Sogari PR, Souto CA. The relationship of serum testosterone to erectile function in normal aging men. J Urol 2002;167:1745-8. doi: 10.1016/ S0022-5347(05)65191-9

40. Kelsey TW, Li LQ, Mitchell RT, Whelan A, Anderson RA, Wallace WH. A validated age-related normative model for male total testosterone shows increasing variance but no decline after age 40 years. PLoS One 2014;9(10):e109346. doi: 10.1371/journal.pone.0109346. eCollection 2014.

41. Harman SM, Metter EJ, Tobin JD, Pearson J, Blackman MR. Longitudinal effects of aging on serum total and free testosterone levels in healthy men. Baltimore Longitudinal Study of Aging. J Clin Endocrinol Metab 2001;86:724-31. doi: 10.1210/jcem.86.2.7219

42. Morley J, Kaiser FE, Perry HM 3rd, Patrick P, Morley PM, Stauber PM, Vellas B, Baumgartner RN, Garry PJ. Longitudinal changes in testosterone, luteinizing hormone, and follicle-stimulating hormone in healthy older men. Metabolism 1997;46:410-3. PMID: 9109845

43. Selby C. Sex hormone binding globulin: origin, function and clinical significance. Ann Clin Biochem 1990;27(part 6):53241. doi: $10.1177 / 000456329002700603$

44. Fabre B, Machulsky NF, Grosman H, Gonzalez D, Oneto A, Repetto EM, Mesch V, Nolazco C, Mazza O, Gidron Y, Berg G. Life events are positively associated with luteinizing hormone in middle age adult men: role of cortisol as a third variable. Stress 2014;17:328-33. doi: 10.3109/10253890.2014. 930431

45. Dembe AE, Yao X, Wickizer TM, Shoben AB, Dong XS. Using $\mathrm{O}^{*}$ NET to estimate the association between work exposures and chronic diseases. Am J Ind Med 2014;57:102231. doi: 10.1002/ajim. 22342

46. Seftel AD. Male hypogonadism. Part I: Epidemiology of hypogonadism. Int J Impot Res 2006;18:115-20. doi: 10.1038/sj.ijir.3901397

47. Zarotsky V, Huang MY, Carman W, Morgentaler A, Singhal PK, Coffin D, Jones TH. Systematic literature review of the risk factors, comorbidities, and consequences of hypogonadism in men. Andrology 2014;2:819-34. doi: 10.1111/andr.274

48. Maggi M, Schulman C, Quinton R, Langham S, UhlHochgraeber K. The burden of testosterone deficiency syndrome in adult men: economic and quality-of-life impact. J Sex Med 2007;4(4 Pt 1):1056-69. doi: 10.1111/j.1743-6109. 2007.00531.x

49. Kaltenboeck A, Foster S, Ivanova J, Diener M, Bergman R, Birnbaum H, Kinchen K, Swindle R. The direct and indirect costs among U.S. privately insured employees with hypogonadism. J Sex Med 2012;9:2438-47. doi: 10.1111/ j.1743-6109. 2012.02810.x

50. Maggio M, Basaria S. Welcoming low testosterone as a cardiovascular risk factor. Int J Impot Res 2009;21:261-4. doi: 10.1038/ijir.2009.25

51. Gencer B, Mach F. Testosterone: a hormone preventing cardiovascular disease or a therapy increasing cardiovascular events? Eur Heart J 2015; pii:ehv439. doi: 10.1093/eurheartj/ ehv439 (Epub ahead of print). 


\section{Profesionalna izloženost buci i razina testosterona u serumu u muškaraca obuhvaćenih ispitivanjem National Health and Nutrition Examination Survey od 1999. do 2004.}

Istraživanja na životinjama uvjerljivo upozoravaju na to da izloženost buci potiskuje lučenje testosterona u mužjaka djelujući na osovinu hipotalamus-hipofiza-testisi. Međutim, gotovo se ništa ne zna o takvom djelovanju buke na ljude. Stoga je cilj ovog istraživanja bio utvrditi postoji li povezanost između profesionalne izloženosti buci i razina testosterona u serumu u reprezentativnom uzorku opće populacije. Uzorak je preuzet iz ispitivanja National Health and Nutrition Examination Survey (NHANES) koje se provodilo od 1999. do 2004. i bilo ograničeno na tada zaposlene muškarce u dobi od 16 do 85+ godina. Povezanost između izloženosti buci (koja je utvrđena bilo na temelju baze podataka i kategorizacije Occupational Information Networka - tzv. O*NET, ili na temelju izjava sudionika o izloženosti buci) i razina ukupnoga (UT) i slobodnoga testosterona (ST) analizirana je linearnim regresijskim modelima. U modelu sa svim varijablama $(n=414)$ ispitanici u trećem kvartilu izloženosti buci prema $\mathrm{O}^{*}$ NET-u imali su statistički značajno niže vrijednosti UT-a i ST-a u odnosu na neizložene radnike: vrijednosti njihova UT-a bile su niže za $58,32 \mathrm{ng} \mathrm{dL} \mathrm{d}^{-1}(95 \% \mathrm{CI}$ $-111,22 ;-5,42)$, a vrijednosti ST-a za 1,58 ng dL $\mathrm{dL}^{-1}$ (95 \% CI: -2,98; -0,18) u odnosu na neizložene. Stratificirana je analiza pokazala da su mlađi radnici, radnici s manjim primanjima, radnici normalne tjelesne mase, oni koji bolje čuju te radnici koji ne nose zaštitu od buke na poslu imali značajno štetnije posljedice od izloženosti od ostalih radnika. Izgledi za hipogonadizam (UT $<300 \mathrm{ng} \mathrm{dL}^{-1}$ ) nisu se značajno povećali s porastom izloženosti prema klasifikaciji $\mathrm{O} * \mathrm{NET}-\mathrm{a} \mathrm{u}$ vrijednosti od jednoga interkvartilnog raspona $(\mathrm{OR}=1,24,95 \% \mathrm{CI}: 0,64 ; 2,39)$. Izloženost buci nije značajno utjecala na pad UT-a kad su analizom bili obuhvaćeni svi radnici koji su sami prijavili izloženost ( $\mathrm{n}=214$ ) nego samo u radnika $\geq 37$ godina, koji su imali za 87,55 ng dL $\mathrm{dL}^{-1}(95 \% \mathrm{CI}$ : $-158,35 ;-16,74)$ niže vrijednosti u odnosu na neizložene radnike. Ovo je istraživanje pokazalo povezanost između izloženosti buci i sniženih razina UT-a i ST-a samo u pojedinim populacijskim podskupinama, a ta povezanost nije bila linearna.

KLJUČNE RIJEČI: buka na poslu, hipogonadizam, izloženost buci, O*NET, testosteron 